\title{
Sociocultural Aspect of Indigeneous-Based Life- Long Learning as Planning Strategy of Empowering Marginal Rural Women
}

\author{
Tri Suminar \\ Nonformal Education Departement, \\ Universitas Negeri Semarang \\ Semarang, Indonesia \\ 1 tri.suminar@mail.unnes.ac.id
}

\begin{abstract}
The purpose of research is to describe and analyze the aspirations of rural women left behind Tribe Samin to achieve independence, potential supporters and obstacles to achieve their aspirations based, diagnose needs empowerment and empowerment strategy planning based on local wisdom. The research method uses a qualitative approach phenomenological perspective. The subjects are adult women Samin tribe. Collecting data using the technique of in-depth interviews, observation and documentation. The validity of the data using a triangulation of sources and methods. Analysis of data using an interactive model. The results showed aspirations of women Samin tribe is able to work to help the family economy in addition to the routine duties as a housewife. They need alternative work skills beyond agriculture and animal husbandry. They have a philosophy of life that is built on local knowledge sociocultural values "Sedulur Singkep". that teaches about the values of truth, simplicity, unity, justice, hard work, compassion, brotherhood, and love the environment, and the universe. Planning strategies women empowerment Samin tribe is lifelong learning sociocultural knowledge of local social capital in the social productive entrepreneurial activity at the same conservation efforts sociocultural and natural environment.
\end{abstract}

Keywords-lifelong learning; social-cultural aspects of indigeneous; empowerment model; marginal rural women.

\section{INTRODUCTION}

Empowering people is an effort to get out of the trap of poverty and backwardness, or the process of enabling and independently society [1]. Community empowerment process adheres to the philosophy of the learning process reversed, as described [2] which is a reversal of the learning process of the regions to the center and the reversal of the flow of information on the agency or organization, where people on learning from the bottom, through the technique of sitting together, questioning and listen. Learning behavior in society occurs through a process of social interaction that takes place in everyday life constantly causes social and cultural changes in society.

Based on these studies can be analyzed program development can be effective, if the role of the community as the subject of development through the empowerment process is optimized based on local cultural wisdom. Forms of empowerment can be achieved through public education based on local wisdom that values the social character of the productive local culture. [3] describes one key to successful management of human resources in development through the empowerment approach is to focus on culture, but through the efforts that are not directly to the culture.

Target community empowerment in this study is underdeveloped rural communities, especially women in Samin tribe who live in the region that has a community "Sedulur Sikep" living in the provision of Central Java. Samin tribe female role as manager of the household and help her husband work as farmers and ranchers, live in conditions of underdeveloped, isolated, poor and less educated [4]. On the other hand they have a lot of free time which can be managed as a process of empowerment to improve their self-reliance and social welfare. Based on these descriptions can essentially reflected that women need empowerment Samin as emancipatory interests that encourage them to participate collectively in development. In addition, they can harness the power potential to regulate or control of their lives, change power through skill and his position became critical and effective participants in society [5].

The phenomenon of underdevelopment of the quality of life of women society Tribe Samin requires agents of social change of culture that is able to manage the process of empowering featured local knowledge of social culture in the form of social capital, minimize weaknesses or inhibitors, so they have the responsibility and independence in the face of the challenge demands progress of society in this age of globalization [6]. According to [7] empowerment of rural communities can achieve its objectives effectively, if you apply some strategy, namely: (a) creating a climate, (b) strengthen, and (c) protect. Efforts to empower communities can be seen from three sides. The first strategy, empowerment through activities to create an atmosphere or climate that allows the potential of developing societies (enabling). The second strategy, empowerment of rural communities through activities that strengthen the potential or community-owned power (empowering). The third strategy, empowered to protect. Protecting seen as an effort to prevent competition is not balanced, and the exploitation of the strong over the weak. 
Institute such opinion, the efforts to realize the acceleration of social change for the tribal community Samin, especially for women empowerment process management requires an efficient and effective. The first management function is planning effective empowerment. Effective planning activities of this empowerment program begins with a strategic assessment through fundamental studies concerning the context of life goals of the program. Planning the implementation of the empowerment of rural communities can be done through: (a) a participatory approach and dialogue in order to formulate a real program to meet their needs through the medium of formal, non-formal and informal institutionalized in rural areas such as: social gathering, recitals, salvation, (b) approach from below and from above (bottom-up and top-down approach) in formulating the program should see the public response to the planned program initiated and the government as a motivator, facilitator and mediator to formulate programs, (c) traditional approach (socio cultural approach), planning and implementation of programs to consider socio-cultural and institutional conditions of rural communities, (d) using agents reformer (change of agent) as field assistants [8]

Based on the fundamental studies can be analyzed to design strategies for the empowerment of rural women left behind in tribal communities that can be used as an alternative Samin innovative and strategic solutions to improve the quality of life of the tribal people Samin effectively without going against the teachings of "sedulur singkep".

\section{RESEARCH METHODS}

This study was designed using a qualitative approach with a phenomenological perspective that utilizes natural setting [9]. This qualitative study aimed to understand the situation, event, group or social interactions women backward village tribal Samin and interpret it as the process of the investigation of a social phenomenon existence of women rate Samin through several activities including: distinguishing, comparing, matching and classifying the existence of women in the social system of cultural background Buddhists Shamanism "sedulur singkep" [10].

The subjects were women Samin tribe village which has a family, including a group of families cannot afford (family income is less than the regional minimum wage), low levels of education. They settled in the north Randublatung, in the teak forests as far as $25 \mathrm{~km}$ from the city center, Village Klopodhuwur, District Banjarejo, Blora.

The primary data source is the women who have a family, female family members (husband, children and parents), the formal and informal community leaders as members of tribal communities Samin, who reside in the village Klopo Dhuwur, District Banjarejo. While secondary data sources are the documents related to the demographic data, the data advantage of local knowledge, agricultural products per year, agricultural land, rural land use, and social organizations in the village.

This study focused on: (a) the existence of women relating to the status and role of women in family life Samin tribe and the community; (b) Aspiration Samin Tribe women to achieve self-reliance; (c) Strength (resource potentials) and weaknesses (lack of) women Samin tribe and the carrying capacity of local wisdom (physical and sociocultural) in order to achieve selfreliance; (d) The basic needs of women in order to achieve selfreliance; (e) women's empowerment strategy Samin tribe to meet basic needs in order to achieve the aspirations toward independence.

The process of collecting data in this study is operationally as follows: (a) non-participant observation conducted in a focused and thorough observation sheet with instruments that are structured to obtain data relating to the existence of women's habits and cultural norms system Samin tribal communities in the daily lives day. (b) In-depth interviews (indepth interviews) with open interviews conducted guideline instrument for capturing data from subjects and key informants with a flexible structure. (c) Study of the documentary, made for the documents related to demographic data, land use data, the data featured local tribal Samin, expenditure data and family income, family burden, including a review of the literature sources recording the activity of the tribal community Samin through a camera photo as documentation.

The validity of the data points to the reliability (trustworthiness) and understanding. Trust the data obtained with honesty, sincerity, diligence and accuracy as well as long stay at the sites. Test the accuracy of data (validity) is obtained from the robustness and compatibility of data through triangulation of sources and methods

Analysis of qualitative descriptions used to analyze the data and information obtained from interviews, observation and documentation. The analysis consists of three flow of activities that occur simultaneously as described [10], namely: data reduction, data presentation and conclusion / verification.

\section{RESULTS AND DISCUSSION}

\section{A. Results of Research}

Tribe Community Samin majority live in the village Klopo Dhuwur. Klopo village Dhuwur part Banjarjo subdistrict administrative area. The village has six hamlets, namely: Watrangkul hamlet, hamlet Badong Kidul, Badong Geneng hamlet, hamlet Sale, Sumengko hamlet, and the hamlet of Coral Pace. The village has an area of 687.705 ha, consisting of 372.730 ha of agricultural land, with a percentage of rain fed or non-irrigated 101.037 ha, and 271, 693 ha for upland while others 104, 450 ha is used for land for housing and settlement, in this village dominated by an oak tree forest, at a height of 35 $\mathrm{m}$ above sea level.

The village has a population of 5.564 inhabitants Klopo Dhuwur by 1688 the number of households, of which 2816 people male - male $(50.6 \%)$ and 2,748 votes $(49.4 \%)$ women. Structure of the population by age can be seen in Table 3.1 below. 
TABLE I. STRUCTURE of POPUlation By AgE

\begin{tabular}{lll}
\hline Structure Age (years) & Amount & Percentage $(\%)$ \\
\hline $04-15$ & 1.327 & 23,8 \\
$16-44$ & 2.452 & 44,1 \\
$45-64$ & 1.459 & 26,2 \\
$>65$ & 326 & 5,9 \\
Total & 5,564 & 100 \\
\hline
\end{tabular}

Based on Table 1 it can be seen the majority of old people Klopo Dhuwur labor force between the ages of 16-44 years, so that people Samin tribe the opportunity to increase productivity.

Viewed from the aspect of education, level of education most people who have settled in this village average - average only able to finish up at the primary level and at the level of junior high school. Thus the claim of formal educational institutions, non-formal and informal is still very large, especially with respect to the implementation of programs of vocational education. Potential support to implement programs of non-formal education such as: Group art as much as 6 group, Youth organizations: 1 piece, activities "muslimatan" (sort of recitation of Islam) 1 piece, and activities "Pokdarwis" (Awareness Group Travel) 1 unit, and the PKK (Guidance Family welfare) 1 unit.

The structure of the educational effect on employment of the population. Structural work Samin majority ethnic communities as farmers and farm workers, as seen in table 3.2 below.

TABLE II. Distribution of Population Tribe SAMin BASED Jobs

\begin{tabular}{llll}
\hline Number & Type of Work & Amount & Percentage \\
\hline 1. & Farmer & 970 & 39,45 \\
2 & Labour farmers & 895 & 36,40 \\
3 & Unemployment & 185 & 7,52 \\
4 & Breeder & 128 & 5,21 \\
5 & Merchants & 122 & 4,96 \\
6 & Private employees & 112 & 4,55 \\
7 & Government & 26 & 1,06 \\
& employees & & \\
8 & Indonesian workers & 16 & 0,65 \\
9 & Military / Police & 5 & 0,20 \\
Total & & 2.459 & 100,00 \\
\hline
\end{tabular}

a. Source: Monograph Dhuwur Klopo village.

Based on Table 2 can be interpreted that the majority of the tribal community Samin worked as a farmer, the farmer's $39.45 \%$ and $36.40 \%$ of workers. The number of people without jobs a number of $7.52 \%$. Those who have not worked a burden on the productive population, thus becoming a social problem that must be solved.

With regard to efforts to build public health, Samin tribe has 1 unit and integrated health centers 7 units. Health infrastructure is still inadequate when compared to the number of inhabitants and the area of the village.

Sociocultural context Samin tribe famous doctrine "Samin Sura Sentiko" which actually Samin has teachings that is, the doctrine and teachings to work hard to pick-degree and dignity of women. The term "samin sikep", "sangkak" and "samar". "Sikep" derives meaningful in the sense of uniting marriage between men and women, because actually in this life according to Samin tribe "Sikep" there are women there are men - men, no day no night, there was no happy hard. They had the principle "just happy drei, series and envy," do not hurt sibling or neighbor and live life with patience, accepting what is given by Gusti (God), and tried to run with the best - well. "Samar" means is unclear existence. While "Samin sangkak" is samin renowned for its refusal sentence or "expect him" against the people - the Netherlands. It is famous in the tribal areas Samin about do not want to receive, defend, or pay taxes because they found soil in live is the land of the Republic of Indonesia and ours, and if this land belongs to us why we should pay taxes to Japanese government who colonized Indonesia.

As a result of the resistance with logical thinking and resourceful the tribe Samin rated resistance. Thus Samin tribe actually teaches how to motivate the people to be conscious of nationalism, giving rise to generation - generation samin public awakening to the initial goal is to liberate Indonesia. They also interpret the independence of the narrow sense, namely freedom for himself and his fellow independent to get welfare

Samin tribe lives living in Klopodhuwur, especially in the hamlet of Coral Pace still follow the teachings of the previous Samin, i.e. accept what it is and it does not hurt to others. But the majority community that left no doctrine "Sedulur Singkep" in terms of their way of thinking in dealing with problems of daily life - today. Slowly began to realize the importance of education for future generations, the need for alternative employment in addition to farmers and accept trade as a job to support the family economy. No differences in men and women in social status. The existence of women commensurate with men, have the equality between them in running this present life.

Samin tribe women continue to learn lifelong values "sedulur singkep" to be taught to their children in family life. In addition to the task of educating, most women Samin tribe wants to increase the income and improve the family economy by participating in the process of agriculture and animal husbandry. Samin tribe of female society most have a passion for change and want to entrepreneurship, but faced obstacles in making this objective cannot be achieved. Society Samin tribe women were very excited and happy, to take up the program the existing empowerment program. They have aspirations and expectations of society samin tribal women, which can work to help her husband with entrepreneurs manage to boost the common welfare. During this community Samin tribe lack of information - information that is useful to actively follow the program - a program to empower women to achieve an expected independence.

The main potential of community-owned Samin tribe is the character values of honesty, the spirit of hard work, perseverance, circumstances accept what is, togetherness and family. Person who does not want to hurt each other, respect women, able to manage the budget well, natural resources, the results of agricultural land. Samin communication technology for the tribe is not foreign, they received advances in communications technology as part of its needs. Social media and mobile are already coloring Samin tribal life, but cannot 
use it as an effort to supplement the family income. Another potential is the existence of the agency social organizations such as group art as much as 6 group, Youth organizations 1 fruit, muslimatan activities (a sort of recitation of Islam) 1 piece, and activities Pokdarwis (Travel Awareness Group) 1 piece, and the PKK as many as 1 unit. Social organitation aims to build for the common welfare.

Efforts to utilize some of the potential Samin tribe towards improving social welfare there are still some obstacles. The main obstacle is still the lack of soft skills and the next obstacle is no creativity of women in the form of creative production skills according to market needs. Similarly, it does not own the skills to manage marketing, manage risk, and calculate profit and loss.

\section{B. Discussion}

Samin tribe women have aspirations for productive work in addition to working as a housewife. Motivation to work is to help the family economy. But they do not know what to do other than routine activities help to work in agriculture and animal husbandry. The attitude and behavior of the Samin tribe women showed signs of people who do not defenseless. They have not been able to understand themselves and their potential and not be able to plan or direct themselves to meet the needs of the family. The condition of women is in contrast to the characteristics of people who have been empowered as described [11], among others: a) be able to understand themselves and their potential; b) able to plan (in anticipation of the next change conditions) and direct himself; c) have the power to negotiate and cooperate mutually to "bargaining power" adequate.

Samin tribe women outside support as agents' reformer to acquire the knowledge and skills to explore the potential of self, reducing personal obstacles and direct the productive actions to meet the needs of the family. This is as described [12] explained that the empowerment essentially aims to help clients get the power, strength and ability to take decisions and actions to be taken and related to the client's self, including reducing personal and social constraints in action. Empowerment through a lifelong learning process by women Samin on their own efforts based on potential self-possessed value sedulur singkep culture is a must. This strategy will result in the accumulation of knowledge, skills and other resources in order to achieve the goal of improving family welfare Samin tribe without depending on help from outside parties. Potential sociocultural Samin tribe is very strategic as social capital (social capital) are productive in the field of social entrepreneurship for the common welfare [13].

Samin tribe women's empowerment through a lifelong learning strategy is corroborated by [14] describes the strategy of achieving empowerment can be done through education and awareness, knowledge emphasizes the educative process. Giving people the skills to work toward effective change. Strategic planning effective empowerment for women Samin tribe is strengthening. Agree [7] empowerment of rural communities can achieve its objectives effectively, when implementing the strategy, creating an atmosphere or climate that allows the potential of developing societies (enabling). The second strategy, empowerment of rural communities through activities that strengthen the potential or community-owned power (empowering). Activities to increase access to knowledge advancement mindset with regard to employment and knowledge to improve health status.

Community empowerment through a lifelong learning process based on local wisdom sociocultural aspects Samin tribe is not only a reference to a person's behavior, but at the same time capable of moving the lives of other villagers were full of civility. If the empowerment strategy is truly embodied the sociocultural aspects of local knowledge can be used as a live view of the wider community. [15] reinforce this strategy is an activity that can be done by local communities to address the various problems in the fulfillment of their needs independently.

Position of women in the culture "sedulur singkep" Samin tribe as a couple of men were harmonious. Thus Samin tribe village community empowerment can be initiated by involving women actively in the social organization and in family life as local wisdom [16]. Effective women's empowerment through a dialogical approach, bottom-up approach and the approach to the sociocultural traditions. [17], [18] and [7] also confirmed through these three approaches can gender mainstreaming as a strategy of community empowerment is designed as an alternative strategy to complement the previous two strategies, the Women in Development (WID) and Gender and Development (GAD).

\section{THE CONCLUSION}

Local wisdom sociocultural Samin tribe puts women have equal footing with men in domestic life. Women have to help her husband meet the aspirations of the family by managing entrepreneurial economy, but they cannot explore the potential of self or self-excellence, and they feel powerless to achieve common prosperity.

Potential self Samin tribe is a strong character values of philosophy teachings "Sedulur Singkep" that form the honest behavior, the spirit of hard work, perseverance, circumstances accept what is, togetherness and family. Person who does not want to hurt each other, respect women, women have an equal footing with men, able to manage the budget well and is open hopefully advances in communications technology. While the potential of the external female Samin tribe is the natural resources of fertile agricultural land, extensive teak plantations, their social organization formed by the people themselves.

Weakness Samin tribe women who become obstacles achieve their aspirations are low education, no experience working outside the home, did not have specific skills for working and village leadership has not provided the opportunity for women Samin tribe follow a vocational training activities.

Lifelong learning process Samin tribe women towards empowerment intensively require several methods such as: participatory, bottom-up and dialogic, dialogic sociocultural.

Women's empowerment strategy Samin tribe focused on social entrepreneurship program processing of agricultural 
products. The combination of philosophical sociocultural values that are embedded Samin tribe into social capital in social entrepreneurship at the same sociocultural values conservation and natural resources.

\section{ACKNOWLEDGEMENTS}

We would like to thank Prof. Dr. Facthur Rokhman, M. Hum, Rector of Universitas Negeri Semarang and Prof. Dr. Totok Sumaryanto F, M Pd, Chairman of the Institute for Research and Community Service which has provided an opportunity for researchers to conduct scientific studies in the Nonformal Education with funding DIPA Universitas Negeri Semarang in 2016. Thanks are also submitted to the committee at the international conference Indonesian Education University (UPI ) Bandung, which has published this article.

\section{REFERENCES}

[1] Prijono, Onny S. Pranarka, A.M.W. Pemberdayaan, Konsep. Kebijakan dan Implementasi. Jakarta: Centre for Strategic and International Studies (CSIS). 1996: pp 88-95.

[2] Chambers, Robert. Participatory Rural Appraisal. Memahami Desa Secara Partisipatif. Kanisius, Yogyakarta, 1992. Pp 102-109

[3] Sudjana, Sistem dan Manajemen Pelatihan: Teori dan Aplikasi. Bandung: Falah Production, 2007, pp 9-16.

[4] [4] Huda, Khirul. Anjar Mukti Wibowo. 2013. Interaksi Sosial Suku Samin dengan Masyarakat Sekitar (Studi Di Dusun Jepang Desa Margomulyo Kecamatan Margomulyo Kabupaten Bojonegoro Tahun 1990-2012). Diunduh http://ejournal.ikippgrimadiun.ac.id/sites/default/files/interaksi\%20sosial \%20suku\%samin.pdf. Tanggal 10 Juli 2016.

[5] [5] Anwar, Manajemen Pemberdayaan Perempuan (Perubahan Sosial Melalui Pembelajaran Vocational Skill pada Keluarga Nelayan). Bandung: Alfabeta, 2007, pp 79

[6] [6] Kutut Suwondo, Civil Society Di Aras Lokal: Perkembangan Hubungan Antara Rakyat dan Negara di Pedesaan Jawa. Yogyakarta : Pustaka Pelajar \& Percik, 2005, pp 70-75
[7] [7] Hubeis, AVS, Pemberdayaan perempuan dari Masa ke Masa. Bogor: IPB Press, 2010, pp 23

[8] [8] Mardikanto, Totok. Poerwoko Soebiato, Pemberdayaan Masyarakat dalam Perpesktif Kebijakan Publik. Bandung: Alfabeta, 2012.

[9] [9] Creswell. John W, Research Design Qualitative, Quantitative and Mixed Methods Approaches, Third Edition, Sage Publications. Thousand Oaks California, 2009:pp 258.

[10] [10] Miles, Matthew B, Huberman, A. Michael.. Analisis Data Kualitatif. Terjemahan Tjetjep Rohendi Rohidi. Jakarta: Universitas Indoensia Press. 1992.

[11] [11] Usman, Sunyoto, Pembangunan dan Pemberdayaan Masyarakat, Yogyakarta : Pustaka Pelajar, . 2004.

[12] [12] Mardikanto, Totok. Poerwoko Soebiato, Pemberdayaan Masyarakat dalam Perpesktif Kebijakan Publik. Bandung: Alfabeta, 2012.

[13] [13] Sartini. Menggali Kearifan Lokal Nusantara Sebuah Kajian Filsafati . Jurnal Filsafat Jilid 37, Nomor 2, 111. 2004.

[14] [14] Isife, B.I, Ochoma, U.C, Constraints to Government's Capacity Building Programmes in Rural Communities of Rivers State, Southern Nigeria. Current Research Journal of Social Sciences 1(2): 23-26, 2009 ISSN: 2041-3246

[15] [15] Anwar, Manajemen Pemberdayaan Perempuan (Perubahan Sosial Melalui Pembelajaran Vocational Skill pada Keluarga Nelayan). Bandung: Alfabeta, 2007.

[16] [16] Adimihardja, ed. 1999. Petani Merajut Tradisi Era Globalisasi: Pendayagunaan Sistem Pengetahuan Lokal dalam Pembangunan, Bandung, Humaniora Utama Press.

[17] [17] Alston, M. "Gender Mainstreaming in practice: A View from Rural Australia". NWSA Jurnal, 18 (2), 123 -147, 2006.

[18] [18] Crespi, I. 2009. "Gender Differences and Equality Issues in Europe: Critical Aspectsof Gender Mainstreaming Policies". International Review of Sociolotionale: RevueIntenationale de Sociologie, 19 (1), 171-188. 